\title{
How to Write Journal Article: Workshop untuk Mahasiswa Tingkat Akhir Program Studi Pendidikan Matematika
}

\author{
Aloisius Loka Son*, Yosepha P.W. Laja, Hendrika Bete, Eduardus B. S. Delvion \\ Pendidikan Matematika, Fakultas Ilmu Pendidikan, Universitas Timor \\ *aloisiuslokason@unimor.ac.id
}

\begin{abstract}
Abstrak
Menulis artikel ilmiah yang baik dan benar sering menjadi momok dan masalah bagi para akademisi termasuk mahasiswa. Karena itu dilakukan kegiatan pengabdian kepada masyarakat (ABDIMAS) ini untuk memberikan pemahaman kepada peserta workshop tentang menulis artikel ilmiah yang baik dan benar, strategi mencari referensi berkualitas, penggunaan aplikasi mendeley, dan strategi menghindari perangkap plagiarisme. Metode yang digunakan dalam workshop ini adalah ceramah, tanya jawab, dan coaching clinic. Pelaksanaan ABDIMAS ini berlangsung selama 1 bulan, dengan pesertanya sebanyak 19 orang. Produk dari kegiatan ini sebagai luaran yang dihasilkan oleh peserta workshop adalah sejumlah artikel ilmiah yang lengkap, kutipan dan daftar pustaka menggunakan aplikasi mendeley, serta artikel ilmiah yang bebas plagiat. Melalui kegiatan ABDIMAS ini dapat menambah wawasan menulis artikel ilmiah bagi peserta yang mulanya tidak familiar, akhirnya menjadi mampu menulis dan menghasilkan suatu artikel ilmiah. Karena itu, direkomendasikan agar workshop penulisan artikel ilmiah menjadi fokus perhatian dan penting untuk dicirikan sebagai dasar pengabdian lebih lanjut.
\end{abstract}

Kata kunci: Artikel ilmiah, Mendeley, Plagiarisme, Workshop.

\section{PENDAHULUAN}

Publikasi karya ilmiah merupakan salah satu indikator kompetensi seorang akademisi, dan menjadi faktor penentu kualitas suatu bangsa. Pernyataan ini mengandung makna bahwa publikasi ilmiah adalah aktivitas wajib bagi para akademisi, yang bukan saja sebagai prasyarat dalam urusan akademik tertentu, tetapi karya ilmiah yang dipublikasi sesorang menjadi sumbangsi untuk masa depan suatu bangsa (Susdarwati \& Dimas, 2021). Begitu pentingnya publikasi karya ilmiah, Pemerintah Republik Indonesia melalui Dirjen Dikti Kemendikbud mengeluarkan Surat Edaran Nomor 152/E/T/2012, mewajibkan mahasiswa dan dosen untuk membuat karya tulis ilmiah dan mempublikasikannya baik di jurnal lokal, nasional, maupun jurnal internasional. Kebijakan pemerintah ini dilakukan untuk membentuk budaya tulis dan publish bagi mahasiswa dan dosen. Melalui publikasi ilmiah akan dapat melahirkan generasi penulis yang kompeten dalam bidangnya, yang berdampak bagi pemerintah untuk mengejar ketertinggalan dalam hal publikasi baik di tingkat nasional, maupun internasional (Nuriana, 2019).

Menindaklanjuti kebijakan pemerintah dalam hal publikasi ilmiah, setiap Perguruan Tinggi di Indonesia menggaungkan wajib publikasi bagi mahasiswa dan dosennya. Khusus bagi mahasiswa, kegiatan publikasi karya ilmiah merupakan syarat wajib kelulusan mahasiswa yang bersangkutan. Kampus menjadikan publikasi karya ilmiah bagi mahasiswa sebagai salah satu syarat untuk mencapai gelar sarjana. Mahasiswa S1, S2, dan S3 diwajibkan untuk membuat karya tulis 
ilmiah dan mempublikasikannya di jurnal kampus maupun jurnal luar kampus (Darmalaksana, 2017; Ismail \& Elihami, 2019). Hal ini sesuai dengan syarat yang dikeluarkan Dikti (2012) dimana mahasiswa sebagai obyek untuk melakukan penulisan artikel ilmiah yang membawa perubahan besar bagi pendidikan Indonesia di Perguruan Tinggi.

Universitas Timor sebagai salah satu Perguruan Tinggi di Indonesia yang terletak di wilayah perbatasan Negara Kesatuan Republik Indonesia dan Negara Republik Democrat Timor Leste, merespon baik kebijakan pemerintah dalam hal publikasi ilmiah dosen dan mahasiswa. Respon tersebut berupa program wajib pengadaan jurnal di setiap Program Studi. Beberapa jurnal yang telah aktif diantaranya adalah Range dan Math-Edu yang dikelola oleh Program Studi Pendidikan Matematika. Kedua jurnal ini merupakah wadah publikasi bagi mahasiswa. Maksudnya adalah mahasiswa yang lulus dari program studi pendidikan matematika Universitas Timor wajib publikasikan karya tulis ilmiahnya, baik pada kedua jurnal ini, maupun pada jurnal kampus lainnya.

Berdasarkan pengalaman tim ABDIMAS yang sekaligus sebagai tim editor jurnal Math-Edu bahwa kualitas naskah artikel yang disubmit oleh mahasiswa masih jauh dari yang diharapkan, baik dari segi konten dan struktur isi, struktur bahasa, cara sitasi, jumlah dan kualitas referensi, maupun kesesuaian dengan

template Math-Edu. Kenyataan ini menunjukkan bahwa mahasiswa belum familiar dengan kegiatan menulis karya tulis ilmiah. Tidak dapat dipungkiri bahwa mahasiswa belum mampu menulis karya tulis ilmiah dalam hal ini adalah artikel ilmiah. Tidak familiar dan tidak mampu menulis artikel ilmiah ini sebenarnya merupakan momok dan masalah bagi kebanyakan mahasiswa di kampus manapun. Hal ini diungkap oleh Ismail \& Elihami (2019) bahwa masih banyak mahasiswa yang belum mampu menulis karya ilmiah. Banyak mahasiswa tidak antusias menulis karya tulis ilmiah karena kurang pengetahuan dan kemampuan tentang penulisan karya tulis ilmiah (Adhikara dkk., 2014)). Budaya menuangkan ide dan gagasan dalam suatu tulisan ilmiah telah berubah menjadi budaya copy-paste yang menyebabkan mental menulis mahasiswa cukup rendah. Ketidakmampuan menulis ini menunjukkan bahwa kebanyakan mahasiswa belum peduli akan pentingnya menulis bagi kehidupan sehari-hari mereka (Saman \& Bakhtiar, 2018).

Mencermati masalah-masalah yang sering dialami oleh mahasiswa dalam menulis artikel ilmiah, maka dipandang perlu dilakukannya workshop dan coaching clinic penulisan artikel ilmiah bagi mahasiswa. Perlunya kegiatan ini untuk membekali pemahaman mahasiswa tentang bagaimana menulis artikel yang baik dan benar, strategi mencari referensi berkualitas dan cara sitasi menggunakan mendeley, serta cara menghindari perangkap plagiarisme.

\section{METODE PELAKSANAAN}

Beberapa sub tema kegiatan untuk mencapai tujuan pengabdian ini antara lain penyampaian materi dan pendampingan penulisan artikel ilmiah yang baik dan benar, strategi mencari referensi yang berkualitas dan cara sitasi menggunakan mendeley, serta strategi menghindari perangkap plagiarisme. Metode workshop yang digunakan adalah ceramah, tanya jawab dan coaching clinic. Melalui ceramah dan tanya jawab dapat membahas bagaimana menulis artikel ilmiah yang baik dan benar, mencari referensi yang berkualitas, serta strategi menghindari perangkap 
plagiarisme. Akhir dari setiap sub tema kegiatan diikuti dengan coaching clinic yang dilakukan secara online.

Berikut ini adalah tabel metode pelaksanaan kegiatan pengabdian.

Tabel 1. Metode Pelaksanaan Kegiatan Pengabdian

\begin{tabular}{|c|c|c|c|}
\hline Tahap & Sub Kegiatan & $\begin{array}{c}\text { Metode } \\
\text { Pelaksanaan }\end{array}$ & Luaran \\
\hline 1 & $\begin{array}{l}\text { Konsep dasar artikel } \\
\text { ilmiah }\end{array}$ & $\begin{array}{l}\text { Ceramah dan } \\
\text { tanya jawab }\end{array}$ & $\begin{array}{l}\text { Memahami konsep dasar } \\
\text { artikel ilmiah }\end{array}$ \\
\hline 2 & $\begin{array}{l}\text { Referensi artikel } \\
\text { ilmiah yang } \\
\text { berkualitas }\end{array}$ & $\begin{array}{l}\text { Ceramah, tanya } \\
\text { jawab, dan praktik }\end{array}$ & $\begin{array}{l}\text { Memahami trik mencari } \\
\text { referensi artikel ilmiah } \\
\text { yang berkualitas }\end{array}$ \\
\hline 3 & $\begin{array}{l}\text { Penggunaan } \\
\text { Aplikasi Mendeley }\end{array}$ & $\begin{array}{l}\text { Ceramah, tanya } \\
\text { jawab, dan praktik }\end{array}$ & $\begin{array}{l}\text { Memahami cara } \\
\text { menggunakan aplikasi } \\
\text { mendeley }\end{array}$ \\
\hline 4 & $\begin{array}{l}\text { Strategi } \\
\text { menghindari } \\
\text { perangkap } \\
\text { plagiarisme }\end{array}$ & $\begin{array}{l}\text { Ceramah, tanya } \\
\text { jawab, dan praktik }\end{array}$ & $\begin{array}{l}\text { Memahami strategi } \\
\text { menghindari perangkap } \\
\text { plagiariasme }\end{array}$ \\
\hline 5 & $\begin{array}{l}\text { Praktek penulisan } \\
\text { artikel ilmiah }\end{array}$ & Coaching clinic & $\begin{array}{l}\text { Menghasilkan artikel } \\
\text { ilmiah }\end{array}$ \\
\hline 6 & $\begin{array}{l}\text { Praktek mencari } \\
\text { referensi berkualitas }\end{array}$ & Coaching clinic & $\begin{array}{l}\text { Sumber referensi yang } \\
\text { berkualitas }\end{array}$ \\
\hline 7 & $\begin{array}{l}\text { Praktek penggunaan } \\
\text { aplikasi mendeley }\end{array}$ & Coaching clinic & $\begin{array}{l}\text { Sitasi artikel ilmiah } \\
\text { menggunakan aplikasi } \\
\text { mendeley }\end{array}$ \\
\hline 8 & $\begin{array}{l}\text { Praktek melakukan } \\
\text { parafrase }\end{array}$ & Coaching clinic & $\begin{array}{l}\text { Artikel ilmiah bebas } \\
\text { plagiat }\end{array}$ \\
\hline
\end{tabular}

Pelaksanaan rangkaian kegiatan seperti pada Tabel 1 berlangsung selama 1 bulan yakni terhitung dari tanggl 02-28 Agustus 2021. Sistem pelaksanaan kegiatan ABDIMAS ini dilaksanakan secara offline dan online, dengan rundown kegiatannya seperti Tabel 2.

Tabel 2. Rundown Kegiatan Pengabdian kepada Masyarakat

\begin{tabular}{lllll}
\hline \multirow{2}{*}{ Sub Kegiatan } & \multirow{2}{*}{ Metode } & \multicolumn{3}{c}{ Minggu } \\
\cline { 3 - 4 } & & I & II III & IV \\
\hline Konsep dasar artikel ilmiah & Ceramah & & & \\
Praktek penulisan artikel ilmiah & CC & & \\
Strategi mencari referensi berkualitas & Ceramah & & \\
Praktek pencarian referensi berkualitas & CC & & \\
Penggunaan aplikasi mendeley & Ceramah & & \\
Praktek penggunaan aplikasi mendeley & CC & & \\
Strategi menghindari perangkap plagiarisme & Ceramah & \\
Praktek parafrase artikel oleh mahasiswa & CC & \\
\hline
\end{tabular}

Keterangan: $\mathrm{CC}=$ Coaching clinic 
Tabel 2 menggambarkan bawah empat sub kegiatan utama dilakukan sepanjang bulan Agustus. Masing-masing sub kegiatan dilaksanakan selama 1 minggu, dengan perincian hari pertama digunakan untuk membekali pemahaman peserta workshop akan topik kegiatan terkait, dan sisa waktu berikutnya selama 1 minggu digunakan untuk praktek.

Peserta kegiatan workshop ini adalah mahasiswa semester akhir Program Studi Pendidikan Matematika Universitas Timor. Jumlah mahasiswa semester akhir sebenarnya cukup banyak, namun mempertimbangkan situasi pandemi COVID-19, sehingga dibatasi saja bagi mahasiswa yang telah melakukan penelitian skripsi. Dengan mempertimbangkan persyaratan tersebut sehingga jumlah peserta secara keseluruhannya sebanyak 19 mahasiswa.

\section{HASIL DAN PEMBAHASAN}

Pelaksanaan kegiatan ABDIMAS ini sesuai dengan rundown kegiatan pada Tabel 2, diawali dengan seremonial pembukaan yang dibuka secara resmi oleh ketua Program Studi Pendidikan Matematika Universitas Timor. Bukti kegiatan seremonial pembukaan dan presentasi materi workshop seperti pada Gambar 1.
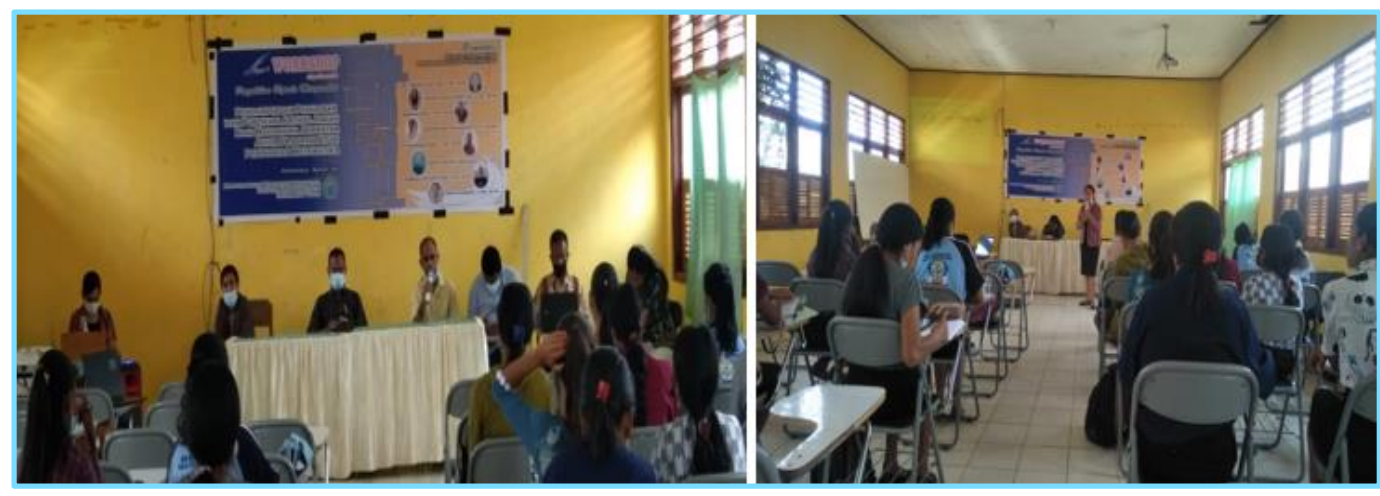

Gambar 1. Seremonial pembukaan dan presentasi materi ABDIMAS

Hasil/luaran dari kegiatan workshop penulisan artikel ilmiah yang telah dilakukan, serta pembahasannya dapat jabarkan pada bagian berikut.

\section{Pendampingan Praktek Penulisan Artikel Ilmiah}

Indikator ketercapaian tujuan sub kegiatan ini dilihat berdasarkan artikel ilmiah yang dihasilkan peserta workshop. Dalam hal ini, bahwa luaran dari sub kegiatan ini adalah artikel ilmiah. Berdasarkan jumlah peserta kegiatan ini yakni sebanyak 19 orang, terdapat 11 peserta yang mampu menuliskan artikel ilmiah. Pendampingan praktek penulisan artikel dilakukan secara online, sehingga tim ABDIMAS menyediakan suatu alamat email khusus untuk dijadikan wadah komunikasi dua arah antara tim ABDIMAS dengan peserta. Artikel ilmiah yang telah ditulis oleh peserta dikirim ke alamat email tersebut, selanjutnya direview oleh tim ABDIMAS dan dikembalikan ke peserta untuk direvisi. Terdapat 11 naskah yang berhasil direview dan dikirim kembali ke peserta melalui email seperti terlihat pada Gambr 2. 


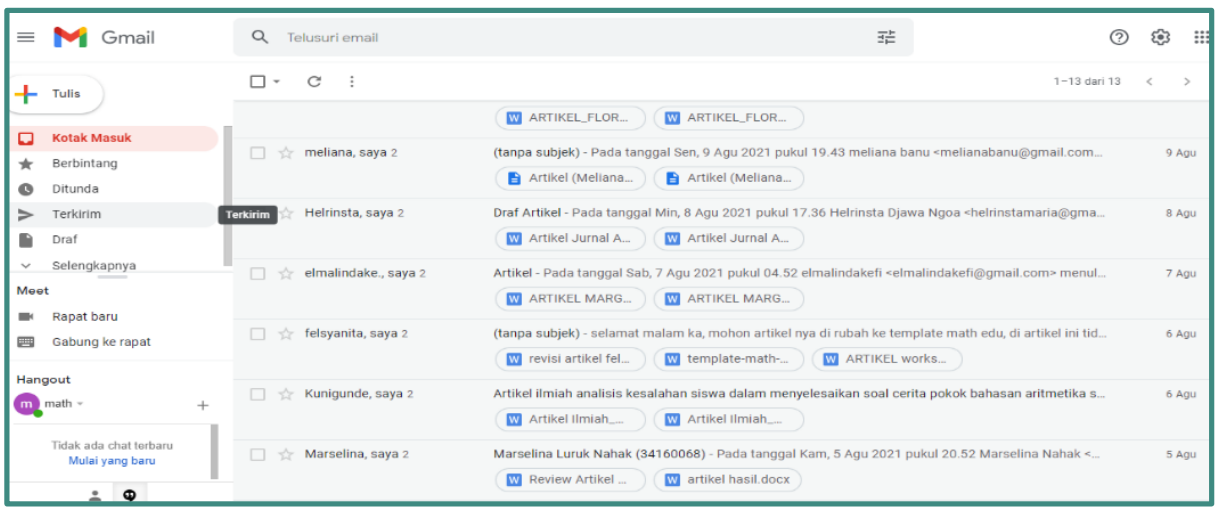

Gambar 2. Bukti pendampingan menulis karya ilmiah via email

Berdasarkan Gambar 2 dilihat bahwa jumlah file dalam bentuk microsoft word oleh masing-masing pengirim lebih dari 1 . Hal ini menunjukkan bahwa 1 filenya merupakan naskah yang dikirim oleh peserta workshop, sedangkan 1 file lainnya merupakan naskah hasil review oleh tim ABDIMAS. Setelah peserta workshop menuliskan artikel ilmiah, selanjutnya diarahkan agar disesuaikan dengan template dari jurnal yang dituju. Beberapa jurnal pendidikan matematika yang menjadi sasaran dari peserta workshop antara lain Aksioma: jurnal matematika dan pendidikan matematika Universitas PGRI Semarang, dan Math-Edu: Jurnal Ilmu Pendidikan Matematika Universitas Timor. Berikut ini adalah petikan artikel ilmiah sesuai template Aksioma, dan template Edu-Math yang berisi catatan/review dari para tim ABDIMAS.

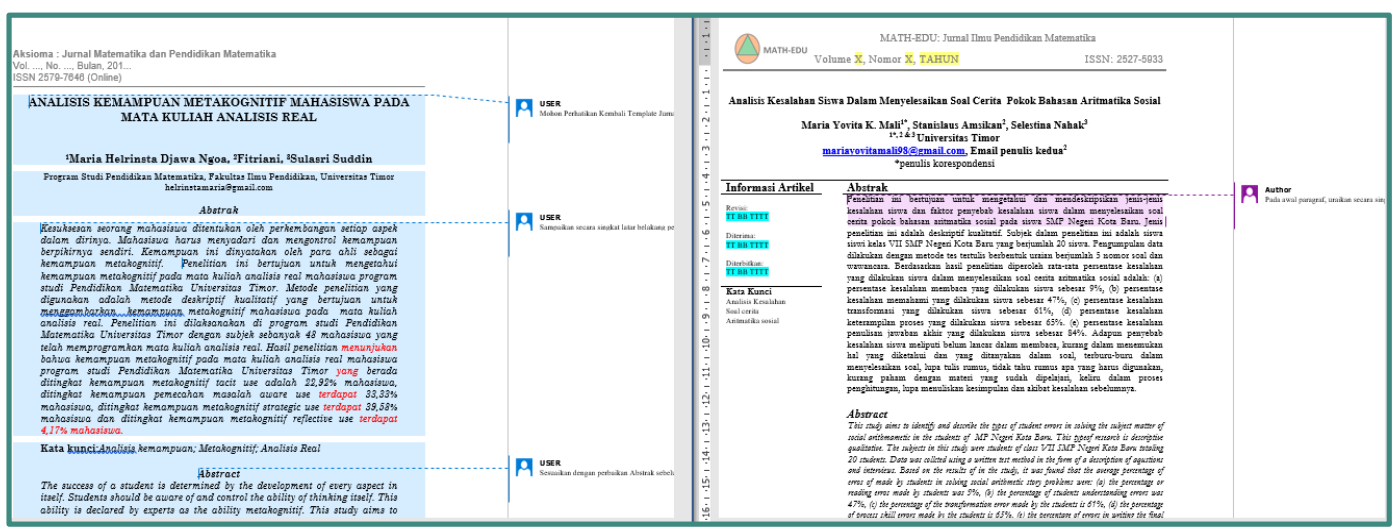

Gambar 3. Naskah peserta sesuai template Aksioma dan Math-Edu.

Gambar 3 merupakan naskah peserta yang telah direview oleh tim ABDIMAS. Petikan Gambr 3 menunjukkan bahwa tujuan sub kegiatan ini tercapai yakni lebih dari 50\% peserta workshop mampu menulis dan menghasilkan suatu artikel ilmiah. Ketercapaian ini menggambarkan adanya peningkatan pemahaman dan kemampuan menulis artikel ini. Melalui kegiatan workshop ini dapat menambah wawasan menulis artikel ilmiah bagi peserta yang dari mulanya tidak familiar dengan kegiatan ini, dan akhirnya mampu menulis dan menghasilkan suatu karya ilmiah. Hal ini sejalan dengan hasil ABDIMAS oleh Ananta, Murnomo, Kartono \& Mulwinda (2016) bahwa artikel ilmiah yang dihasilkan oleh mahasiswa merupakan bukti bertambahnya pengetahuan tentang penulisan artikel sebagai efek positif dari 
pelatihan dan pendampingan yang dilakukan. Kegiatan sejenis ini mampu memberikan pemahaman dan keterampilan baik pengetahuan umum maupun secara teknis dalam penulisan artikel ilmiah (Salam, dkk. 2017).

\section{Pendampingan Praktek Mencari Referensi Berkualitas dan Penggunaan Aplikasi Mendeley}

Tujuan sub kegiatan ini tercapai jika 1) daftar pustaka yang digunakan dalam naskah artikel yang dihasilkan peserta workshop lebih banyak menggunakan referensi-referensi yang bersumber pada jurnal nasional maupun internasional, dan 2) sitasi naskah artikel peserta workshop menggunakan aplikasi mendeley. Saat penyampaian materi kegiatan, peserta workshop dibekali dengan strategi mencari referensi berkualitas misalnya melalui google scholar.com. Selain membekali peserta workshop dengan materi di atas, tim ABDIMAS menyediakan aplikasi mendeley sehingga dapat diinstal dan dipraktekan secara langsung oleh para peserta workshop. Kegiatan praktek penggunaan aplikasi mendeley dituntun dan diarahkan oleh para tim ABDIMAS.

Luaran dari sub kegiatan ini ditunjukkan dengan sumber referensi yang digunakan peserta workshop, serta bentuk sitasi menggunakan aplikasi mendeley. Terdapat sejumlah naskah peserta workshop yang referensinya bersumber dari jurnal, serta sitasinya menggunakan aplikasi mendeley, seperti pada Gambar 4.

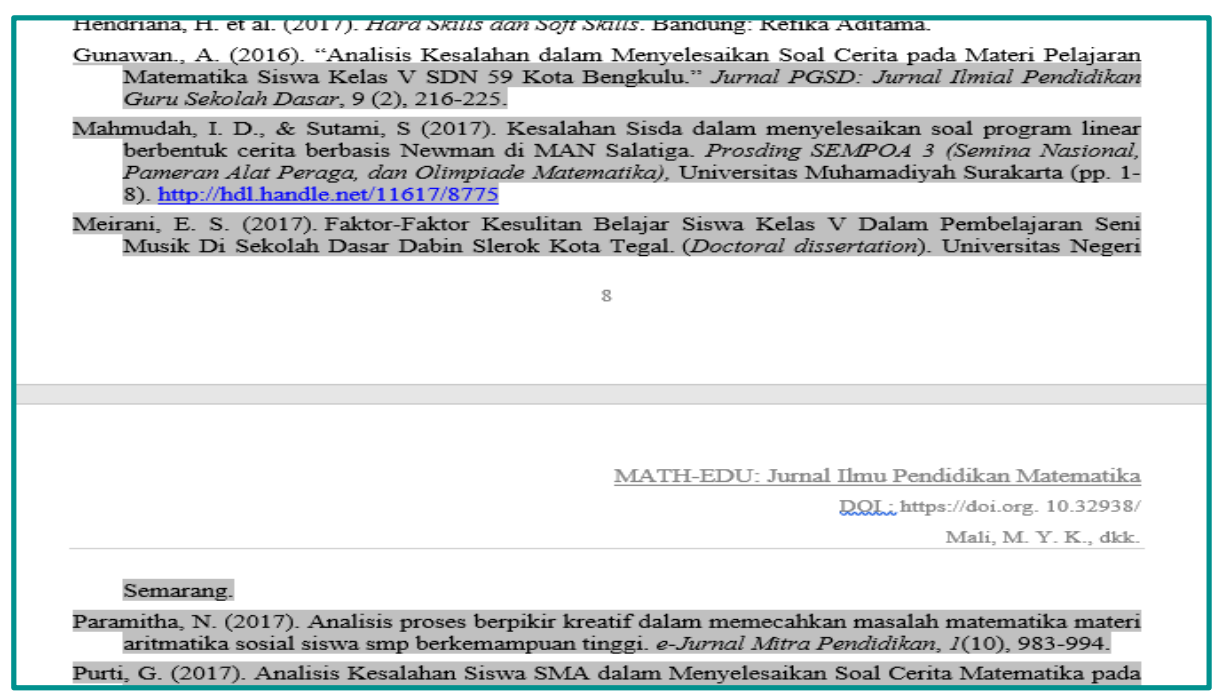

Gambar 4. Petikan daftar pustaka naskah peserta workshop

Gambar 4 merupakan petikan daftar pustaka artikel peserta workshop menggunakan aplikasi mendeley. Hal ini ditandai dengan berubahnya warna shading ketika diklik sumber-sumber referensi pada bagian daftar pustaka. Naskah peserta workshop dalam Gambar 4 rencananya akan disubmit ke Math-Edu: jurnal pendidikan Matematika. Berhasilnya peserta workshop menggunakan referensi yang bersumber dari jurnal, dan menggunakan aplikasi mendeley ini menggambarkan antusiasme dan kesadaran peserta dalam mengikuti kegiatan dimaksud. Mereka merasakan manfaat dari kegiatan ABDIMAS ini, dan menyadari pentingnya memahami dan menggunaka aplikasi mendeley. Kegiatan seperti ini memberikan manfaat kepada peserta pengabdian berupa pengetahuan akan 
pentingnya penggunaan aplikasi mendeley dalam menulis karya ilmiah (Pahmi dkk., 2018).

Pengakuan dari peserta workshop bahwa penggunaan aplikasi mendeley tidak akan terjadi kesalahan dalam mengatur sitasi dan referensi. Referensi yang disitasi otomatis akan terekam pada bagian daftar pustaka, sehingga sangat tidak mungkin terdapat kesalahan-kesalahan seperti perbedaan antara sumber sitasi dan referensi, adanya sumber sitasi tapi tidak terbaca pada bagian daftar pustaka atau sebaliknya, dan kesalahan-kesalahan lainnya. Penggunaan aplikasi mendeley mengatasi masalah-masalah seperti di atas, termasuk juga kesalahan tulis nama, tahun, judul referensi/literatur maupun penerbit (Supianti, 2018). Aplikasi ini sangat membantu dalam mengatur sitasi dan referensi karena menawarkan fitur yang dapat melacak keaslian sitasi dan referensi yang digunakan (Pramiastuti, Rejeki \& Pratiwi, 2020).

\section{Pendampingan Praktek Melakukan Parafrase}

Sub kegiatan ini diawali dengan penyampaian materi tentang strategi menghindari perangkap plagiarisme, yang dilakukan pada hari pertama minggu ke-4. Petikan slide pertama PPT yang disampaikan saat presentasi, seperti Gambar 5.

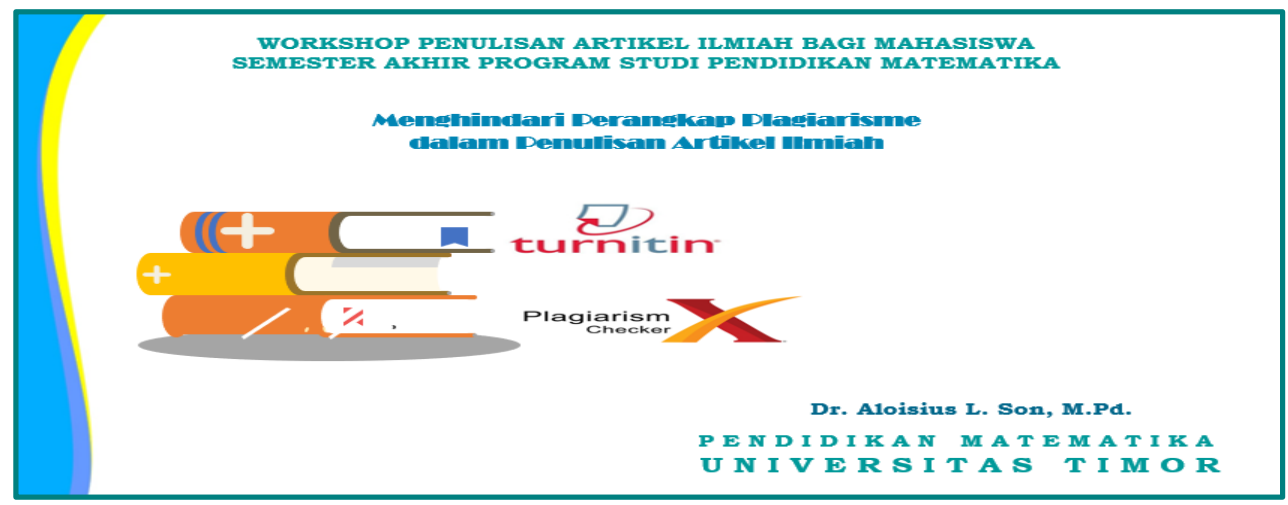

Gambar 5. Petikan slide pertama tentang menghindari perangkap plagiarisme.

Penyampaian materi ini bertujuan untuk memfasilitasi pemahaman peserta workshop tentang strategi-strategi untuk menghindari perangkap plagiarisme. Selanjutnya artikel ilmiah yang dihasilkan oleh peserta dicek plagiarismenya menggunakan aplikasi plagiarism CheckerX. Output dari pengecekan ini menampilkan besarnya persentase plagiarism/similarity artikel yang ditulis peserta ABDIMAS. Pada pengecekan awal, dideteksi besarnya persentase similarity artikel peserta yang cukup tinggi, bahkan ada naskah yang mencapai $50 \%$.

Berdasarkan hasil pengecekan awal tersebut, selanjutnya diberikan tugas kepada peserta ABDIMAS untuk melakukan parafrase kalimat atau paragraf yang terdeteksi plagiat. Parafrase dilakukan sendiri oleh peserta workshop baik secara manual maupun menggunakan aplikasi smodin.me atau quilbot tool. Pendampingan praktek parafrase dilakukan secara online. Peserta workshop melakukan parafrase dan mengirimkan hasilnya melalui email, selanjutnya tim ABDIMAS mengecek besarnya persentase plagiarisme, dan mengirimkannya kembali melalui email. Pengecekan similarity artikel ilmiah dilakukan hingga tahap kedua dan juga ada yang sampai tahap ketiga. Tim ABDIMAS menetapkan standar plagiat maksimal sebesar 20\%. Penngecekan tahap terakhir diperoleh beberapa artikel peserta workshop yang besar persentase similarity mencapai standar yang ditentukan. 
Berikut ini adalah petikan hasil cek plagiarism/similarity artikel salah satu peserta workshop, yang persentase similarity mencapai standar yang ditentukan.

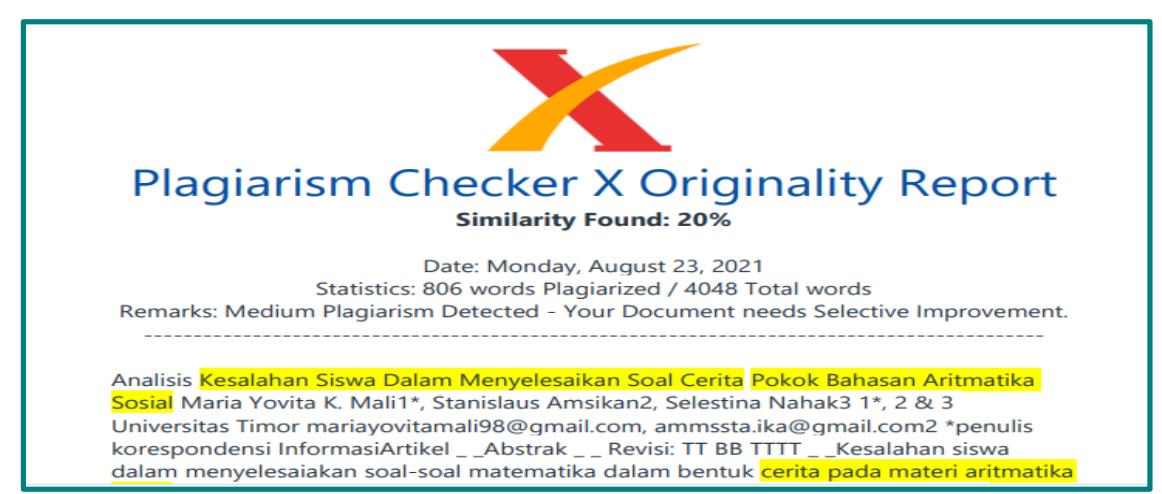

Gambar 6. Petikan hasil cek plagiarime artikel peserta workshop.

Gambar 6 menunjukkan bahwa besarnya persentase naskah peserta workshop sebesar 20\%. Kalimat atau paragraf yang sama atau terdeteksi plagiat adalah kalimat/paragraf yang ditandai dengan warna kuning. Hal ini karena pemeriksaan plagiarisme menggunakan aplikasi plagiarism CheckerX. Pada bagian terakhir output pemeriksaan terdeteksi sumber website yang memuat naskah yang dicopy oleh author. Warna frase/kalimat/paragraf yang terdeteksi plagiat berbeda jika pemeriksaannya menggunakan aplikasi lain seperti Turnitin. Jika pemeriksaan menggunakan aplikasi turnitin, maka frase atau kalimat atau paragraf yang mengandung unsur plagiat akan ditandai dengan warna berbeda-beda, serta dapat terdeteksi sumber website yang memuat tulisan yang sama (Yandra, Zamzami \& Febriadi, 2018). Naskah artikel yang dicek, dan terdeteksi plagiat maka tugas peserta workshop adalah melakukan parafrase. Melakukan parafrase berarti menginterpretasi ide yang dikutip dengan menggunakan kata-kata sendiri tanpa mengubah makna/arti dari ide tersebut. Walaupun melakukan interpretasi terhadap ide yang dikutip namun wajib hukumnya untuk tetap menyebutkan sumber referensi (Sahla, Mukhlisah, Julkawait \& Irwansyah, 2019)

\section{SIMPULAN}

Kegiatan pengabdian kepada masyarakat ini dapat menambah wawasan menulis artikel ilmiah bagi peserta. Selain itu dapat memberikan pengetahuan kepada peserta mengenai strategi mencari referensi yang berkualitas, menggunakan aplikasi mendeley, dan melakukan parafrase untuk menghindari perangkap plagiarisme. Hal ini dibuktikan melalui produk yang dihasilkan oleh peserta ABDIMAS yaitu sejumlah artikel ilmiah yang lengkap, kutipan dan daftar pustaka menggunakan aplikasi mendeley, serta artikel ilmiah yang bebas plagiat. Karena itu, direkomendasikan agar workshop penulisan artikel ilmiah menjadi fokus perhatian dan penting untuk dicirikan sebagai dasar pengabdian lebih lanjut.

\section{UCAPAN TERIMA KASIH}

Terima kasih kepada ketua Program Studi Pendidikan Matematka, serta Lembaga Penelitian dan Pengabdian kepada Masyarakat Universitas Timor yang telah 
memberikan ruang kepada tim ABDIMAS untuk melakukan kegiatan pengabdian ini.

\section{DAFTAR PUSTAKA}

Adhikara, M. F. A., Handayani, S., Jumono, S., \& Darmansyah, D. (2014). Pelatihan Penyusunan Artikel Publikasi pada Mahasiswa Perguruan Tinggi di Jakarta Barat. Jurnal Abdimas, 1(1), 41-53.

Ananta, H., Murnomo, A., Kartono, R., \& Mulwinda, A. (2017). Pelatihan dan Pendampingan Penulisan Artikel Ilmiah untuk E-Journal Mahasiswa Jurusan Teknik Elektro FT Unnes. Rekayasa: Jurnal Penerapan Teknologi dan Pembelajaran, 14(2), 121-126. https://doi.org/10.15294/rekayasa.v14i2.8971

Darmalaksana, W. (2017). Riset Berbasis Outcome: Perencanaan, pelaksanaan dan pelaporan. Diakses dari digilib.uinsgd.ac.id.

Susdarwati, S., \& Dimas, A. (2021). Seminar Publikasi Karya Ilmiah: Strategi Publikasi Artikel dan Kiat-Kiat Lolos Publikasi dalam Jurnal. IJCE (Indonesian Journal of Community Engagement), 2(1), 25-31. https://doi.org/10.37471/ijce.v2i1.224

Ismail, I., \& Elihami, E. (2019). Pelatihan Penyusunan Artikel Publikasi Ilmiah bagi Mahasiswa Perguruan Tinggi STKIP Muhammadiyah Enrekang. Maspul Journal of Community Empowerment, 1(1), 12-20.

Nuriana, D. (2019). Publikasi Melahirkan Generasi Penulis Yang Intelek. Diakses dari repo.stikesicme-jbg.ac.id.

Pahmi, P., Ardiya, A., Syahfutra, W., Wibowo, A. P., Niah, S., \& Febtiningsih, P. (2018). Pelatihan Penggunaan Mendeley untuk Referensi dalam Menulis Karya Ilmiah bagi Guru SMA Handayani Pekanbaru. Jurnal Pengabdian UntukMu NegeRI, 2(2), 35-39. https://doi.org/10.37859/jpumri.v2i2.849

Pramiastuti, O., Rejeki, D. S., \& Pratiwi, A. (2020). Pengenalan dan Pelatihan Sitasi Karya Ilmiah Menggunakan Aplikasi Mendeley. JABI: Jurnal Abdimas Bhakti Indonesia, 1(1), 24-30. https://doi.org/10.36308/abp.v1i1.178

Sahla, W. A., Mukhlisah, N., Julkawait, \& Irwansyah, R. (2019). IbM-Pelatihan Teknik Penulisan Parafrase Untuk Skripsi Mahasiswa Sebagai Upaya Menghindari Plagiarisme. Jurnal Impact: Implementation and Action, 1(2), 162-168. https://doi.org/10.31961/impact.v1i2.645

Salam, R., Akhyar, M., Tayeb, A. M., \& Niswaty, R. (2017). Peningkatan Kualitas Publikasi Ilmiah Mahasiswa dalam Menunjang Daya Saing Perguruan Tinggi. Jurnal Office, 3(1), 61-65. https://doi.org/10.26858/jo.v3i1.3463

Saman, A., \& Bakhtiar, M. I. (2018). Karya Tulis Ilmiah bagi Mahasiswa STKIP Andi Matappa Kabupaten. Jurnal Terapan Abdimas, 3(1), 39-43. http://doi.org/10.25273/jta.v3i1.2165

Supianti, I. I. (2018). Mendeley sebagai Alat Bantu dalam Penyusunan Referensi Artikel. In Prosiding Seminar Nasional \& Workshop, 1 (1), 168-177. Magister Pendidikan Matematika Unversitas Pasundan.

Yandra, A., \& Febriadi, B. (2018). Pelatihan penggunaan aplikasi pendeteksi palgiat untuk dosen universitas lancang kuning. Dinamisia: Jurnal Pengabdian Kepada Masyarakat, 2(2), 283-286. https://doi.org/10.31849/dinamisia.v2i2.1252 